\title{
PARTICIPACE STUDENTŮ NA TVORBĚ PODPŮRNÝCH VÝUKOVÝCH MATERIÁLŮ V PŘEDMĚTU NĚMČINA PRO BANKOVNICTVÍ
}

\author{
Blanka Blažková ${ }^{\text {; }}$ Eva Kahounová ${ }^{2}$ \\ Západočeská univerzita v Plzni, Ústav jazykové přípravy, Oddělení německého jazyka, \\ Univerzitní 22, 30100 Plzeň, Česká republika \\ e-mail: ${ }^{1}$ blazkovb@ujp.zcu.cz; ${ }^{2}$ kahounov@ujp.zcu.cz
}

\begin{abstract}
Abstrakt
Studenti bakalářského studia Fakulty ekonomické Západočeské univerzity v Plzni mají možnost prohloubit si schopnosti a znalosti získané studiem odborných předmětů prostřednictvím nadstavbových odborných kurzů vyučovaných v němčině. Cílem odborných jazykových kurzů je adekvátní př́prava studentů na profesní život a zprostředkování prakticky zaměřených kompetencí. Článek se věnuje participaci studentů na tvorbě podpůrných materiálů v předmětu Němčina pro bankovnictví. Pro představení studentských projektů byl zvolen grafický online nástroj Canva. Individuální prezentace studentů byly vytvořeny formou interaktivních videí pomocí online nástroje EdPuzzle. Oblíbenost online nástrojů byla ověřena $\mathrm{v}$ dotazníku.
\end{abstract}

\section{Keywords}

Banking; Online tools; Canva; EdPuzzle; Questionnaire.

\section{Úvod}

Ústav jazykové prŕpravy Západočeské univerzity v Plzni zajišt’uje neoborovou jazykovou výuku studentům 9 fakult ZČU. Pro studenty Fakulty ekonomické zabezpečuje výuku povinně volitelných předmětů, které jsou zaměřené na profesní a odbornou komunikaci. Od druhého ročníku bakalářského studia zahrnuje studijní plán také nadstavbové odborné jazykové kurzy. Nadstavbové kurzy v němčině se specializují na marketing, bankovnictví a cestovní ruch. Cílem odborných jazykových kurzů je adekvátní př́prava studentů na profesní život a zprostředkování prakticky zaměřených kompetencí. Po absolvování těchto specializovaných kurzů studenti disponují velmi dobrou jazykovou kompetencí a mají také velmi dobré odborné znalosti v oblastech marketingu, bankovnictví nebo cestovního ruchu.

Ke specializovaným povinně volitelným předmětům bakalářského studia náleží napřr. Pojišt'ovnictví nebo Bankovnictví. Obsah a zaměření obou zmiňovaných předmětů korespondují s nadstavbovým kurzem Němčina pro bankovnictví a efektivně využívají nabyté vědomosti $\mathrm{k}$ prohloubení odborných znalostí at' už formou aktivního zapojení studentů do výuky vlastními prezentacemi nebo kooperací s vybranými subjekty.

\section{Němčina pro bankovnictví (NBA)}

\subsection{Cíl a obsah předmětu}

Cílem předmětu Němčina pro bankovnictví je prohloubit komunikativní kompetence, rozšířit slovní zásobu a základní frazeologii v oblasti bankovnictví, osvojit si orientaci v systému německého bankovnictví, prohloubit jazykové kompetence na úrovni B2 dle Společného evropského referenčního rámce pro jazyky. 
Předmět se zabývá následujícími tématy: Německý bankovní systém; Úlohy, služby a struktura banky; Založeni konta, druhy kont; Bankovni karty a jejich druhy; Platebni styk; Kreditní karty; E-banking; Úvěry, SCHUFA - insolvenční ř́zení; Vklady, cenné papiry, spoření, burza, strategie plánování; Euro, Evropská centrální banka, ochrana peněz.

Student je schopen po absolvování kurzu vést obchodní jednání v německém jazyce, orientovat se $\mathrm{v}$ systému německého bankovnictví, prezentovat a argumentovat $\mathrm{v}$ německém jazyce, vysvětlit bankovní výrazy.

„I když je bankovním jazykem především angličtina, nelze podcenit fakt, že naši nejvýznamnějši obchodní a finančni partneři v sousednich zemích mluví německy a že pro úspěšné jednáni je znalost jazyka velmi důležitá. Navíc ne všichni naši německy mluvíci zákazníci a partneři mluví tak dobře anglicky, aby mohli vést obchodní jednáni. “ [1, s. 3]

\section{$2 \quad$ Výuka v letním semestru 2020/21}

\subsection{Platforma Microsoft Teams}

Výuka předmětu Němčina pro bankovnictví probíhala v letním semestru 2020/21 online v prostředí Microsoft Teams. Veškeré podklady pro výuku byly uloženy na této platformě, což umožňovalo plynulou výuky bez nutnosti vyhledávat materiály jinde.

\subsection{Pracovní listy}

Pro výuku předmětu bylo vytvořeno celkem 9 pracovních listů, které obsahují teoretický základ tématu, cvičení pro upevnění slovní zásoby a rovněž online odkazy vztahující se k probíranému tématu. Pro názornost uvádíme př́klad z pracovního listu Kredite - Úvěry (Fig. 1)

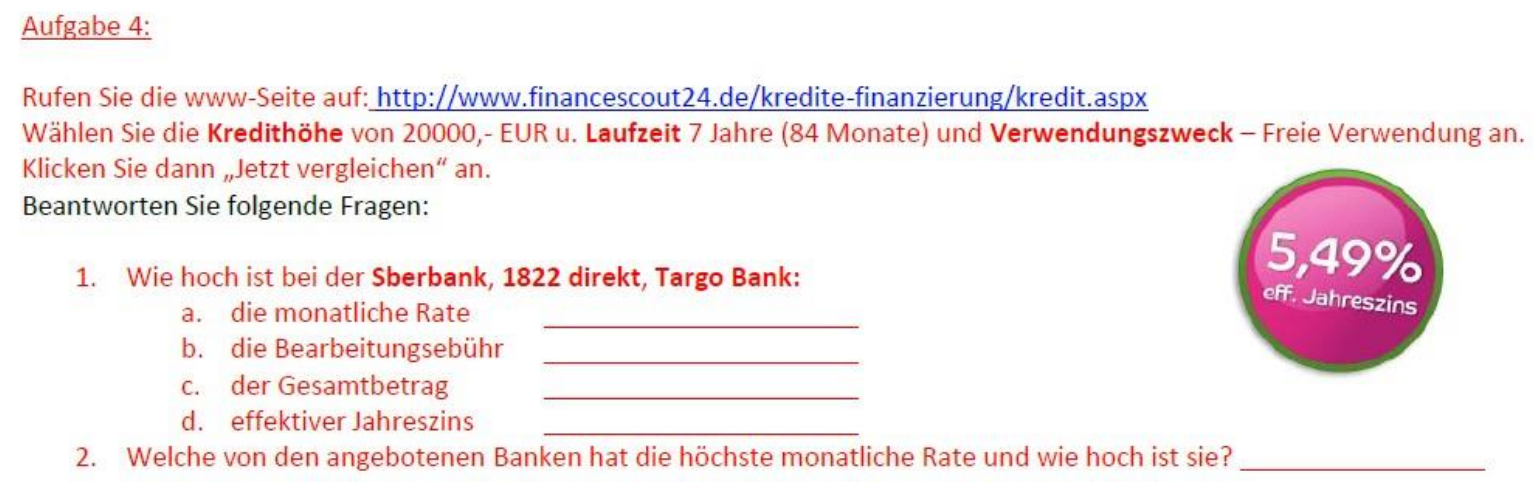

Zdroj: Vlastní (UJP ZČU)

Fig. 1: Př́klad online cvičení z pracovního listu Kredite

\section{Participace studentů na tvorbě podpůrných materiálů ve výuce}

Velkým př́nosem digitálních technologií ve výuce je jejich potenciál vyvolat aktivní osobní zapojení studentů do výukových aktivit. A právě participace studentů na tvorbě podpůrných výukových materiálů byla předmětem dvou prezentací, jedné skupinové a jedné individuální.

Naštěstí existuje řada možností, jak výuku na dálku oživit a udělat ji interaktivní. Jaké nástroje k tomu využít? Co může dobře fungovat i pro vzdělávání dospělých? [2]. EdPuzzle a Canva k těmto nástrojům právem patř́i. 


\subsection{Individuální prezentace v EdPuzzle}

Pro individuální studentské prezentace byla v akademickém roce 2020/21 zvolena interaktivní internetová aplikace EdPuzzle. V přehledu interaktivních aplikací na stránkách Celoživotního a distančního vzdělávání při Západočeské univerzitě v Plzni je aplikace EdPuzzle zařazena do seznamu, který vznikl jako podpora pro využití technologií ve výuce a zajištění distančních aktivit. Jsou zde umístěny návody pro využívání nejznámějších portálů, včetně ukázkových aktivit [3].

Pomocí nástroje EdPuzzle lze do videí nahraných z YouTube, TEDed nebo Khan Academy vkládat interaktivní otázky otevřené (Open-ended question) nebo otázky s možností výběru z několika odpovědí (Multiple-choice question). Na vložené otázky studenti musí během sledování videa odpovědět. Aplikace nabízí okamžitou zpětnou vazbu o splnění a správnosti odpovědí. K prripojení stačí chytrý mobilní telefon, tablet nebo počítač [4].

Návod, jak připravit individuální prezentaci, byl realizován vyučující právě v EdPuzzle a byl dostupný v souborech v Microsoft Teams. Studenti tak měli návod kdykoliv k dispozici.

Nejdříve byla vyučující vybrána krátká produktová videa bankovních služeb na YouTube. Každý student dostal přiděleno jedno video a jeho úkolem bylo jeho zpracování v EdPuzzle dle návodu vyučující. Vytvořené prezentace s vloženými interaktivními otázkami studenti ukládali pod jeden účet založený v EdPuzzle. Každý student si tedy procvičil slovní zásobu obsaženou ve videích a zodpověděl na vložené otázky.

Po vytvoření interaktivních otázek je na časové ose zvýrazněna pauza ve formě malé kapky, v níž se objeví studentem zadaná otázka. V př́kladu na Fig. 2 je uvedeno celkem pět otázek. Obrázek 3 pak znázorňuje jednu z Multiple-choice question (Fig. 3), na Fig. 4 je pak př́íklad Open-ended question.

Jak se studentům práce s EdPuzzle líbila či nelíbila, je obsahem 4. kapitoly tohoto článku.

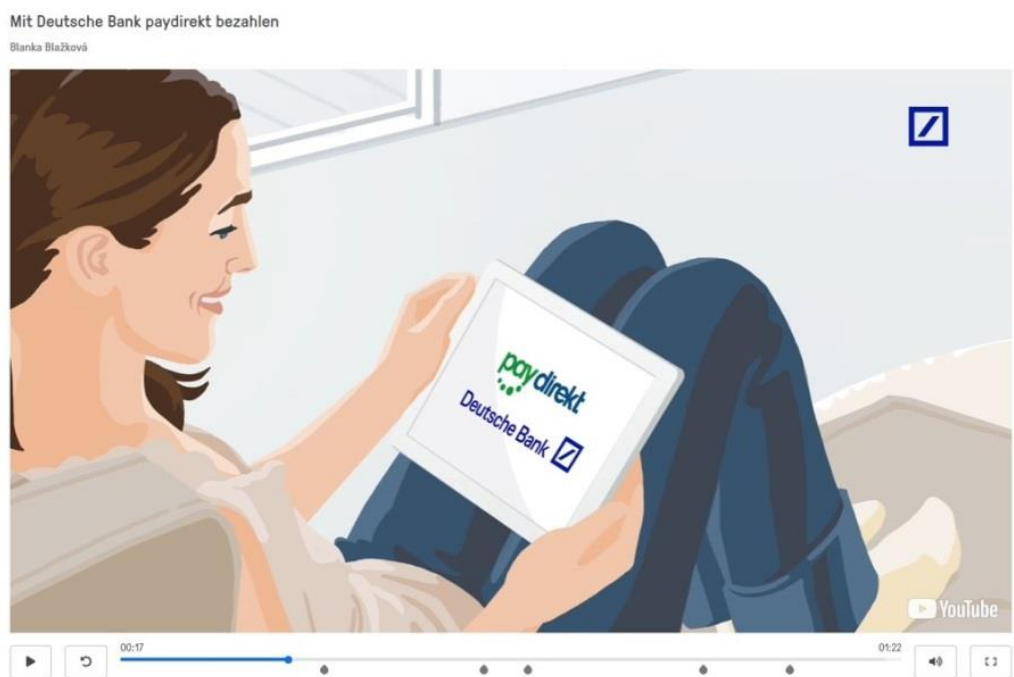

Zdroj: Vlastní (UJP ZČU)

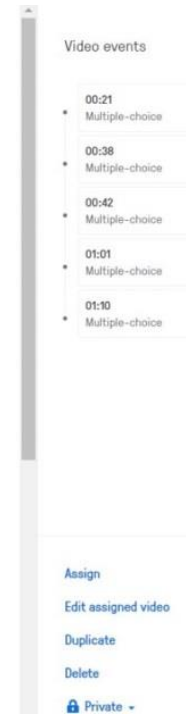

Fig. 2: Př́klad 1 EdPuzzle 


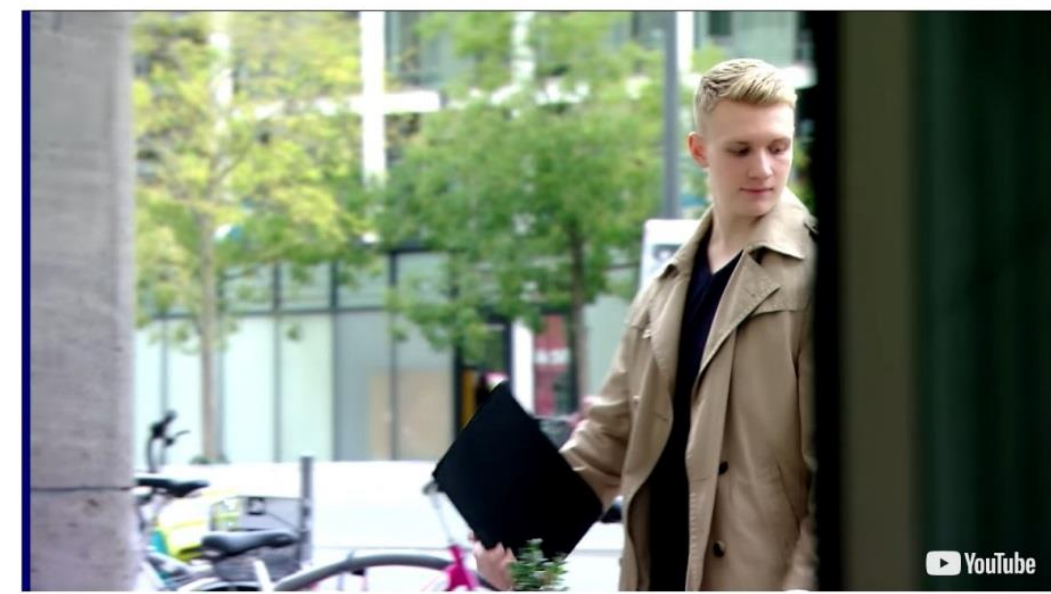

E MULTPLE CHOICE QUESTION

Wo kann man ein Praktikum machen?
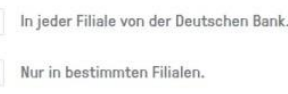

Rewatch Skip

Zdroj: Vlastní (UJP ZČU)

Fig. 3: Př́klad 2 EdPuzzle

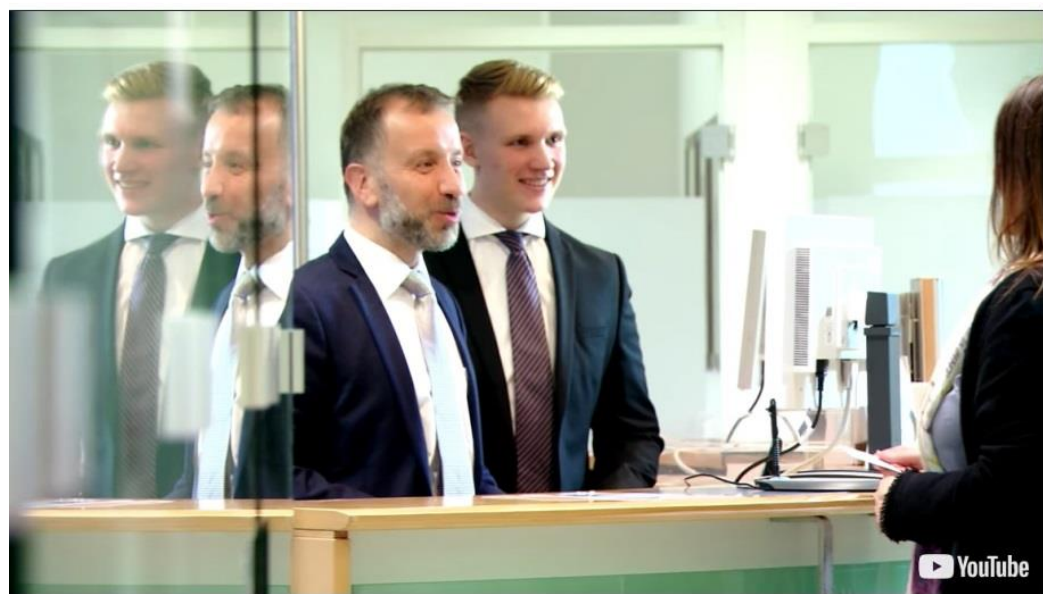

OPEN ENDED QUeSTION

Was solltest du nicht beim persönlichen Gespräch mit Bankangestellten vergessen?

Zdroj: Vlastní (UJP ZČU)

Fig. 4: Př́lklad 3 EdPuzzle

\subsection{Skupinový projekt Meine Bank v Canvě}

Pro skupinový projekt Meine Bank byla vybrána grafická aplikace Canva.

Canva je výborný grafický editor se spoustou šablon, se kterými jednoduše vytvoříte vlastní zajímavé materiály (infografiky, plakáty, prezentace, př́spěvky na Facebook, pro blog, atd...) [5].

V první hodině byli studenti seznámeni s požadavky na obsah prezentace. V prezentaci museli představit svou, na trhu neexistující banku s odděleními a funkcemi, které jednotliví členové projektového týmu zastávali. Na prrípravu měli 7-8 týdnů. Příklad zadání uvedený v němčině znázorňuje obrázek 5 (Fig. 5). 


\section{NBA - Ihre Bank (Projekt)}

- Bilden Sie zwei Projektgruppen

* Jede Gruppe stellt eine eigene nicht existierende Bank vor

* In den nächsten Unterrichtsstunden gebe ich Ihnen 10 Minuten Zeit für die Beratung

* Ihre Bank sollte alle wichtigen Informationen umfassen (Name, Rechtsform, Geschichte, Sitz, Gründer, Gründungsjahr, Organigramm, Abteilungen, Ihre Zuständigkeiten, Anzahl der Mitarbeiter, Kunden, Dienstleistungen, Niederlassungen,...)

* Ihre Bank präsentieren Sie dann in ca 8 Wochen

+ Die Präsentation (15 Minuten) bilden Sie nach https://www.canva.com/

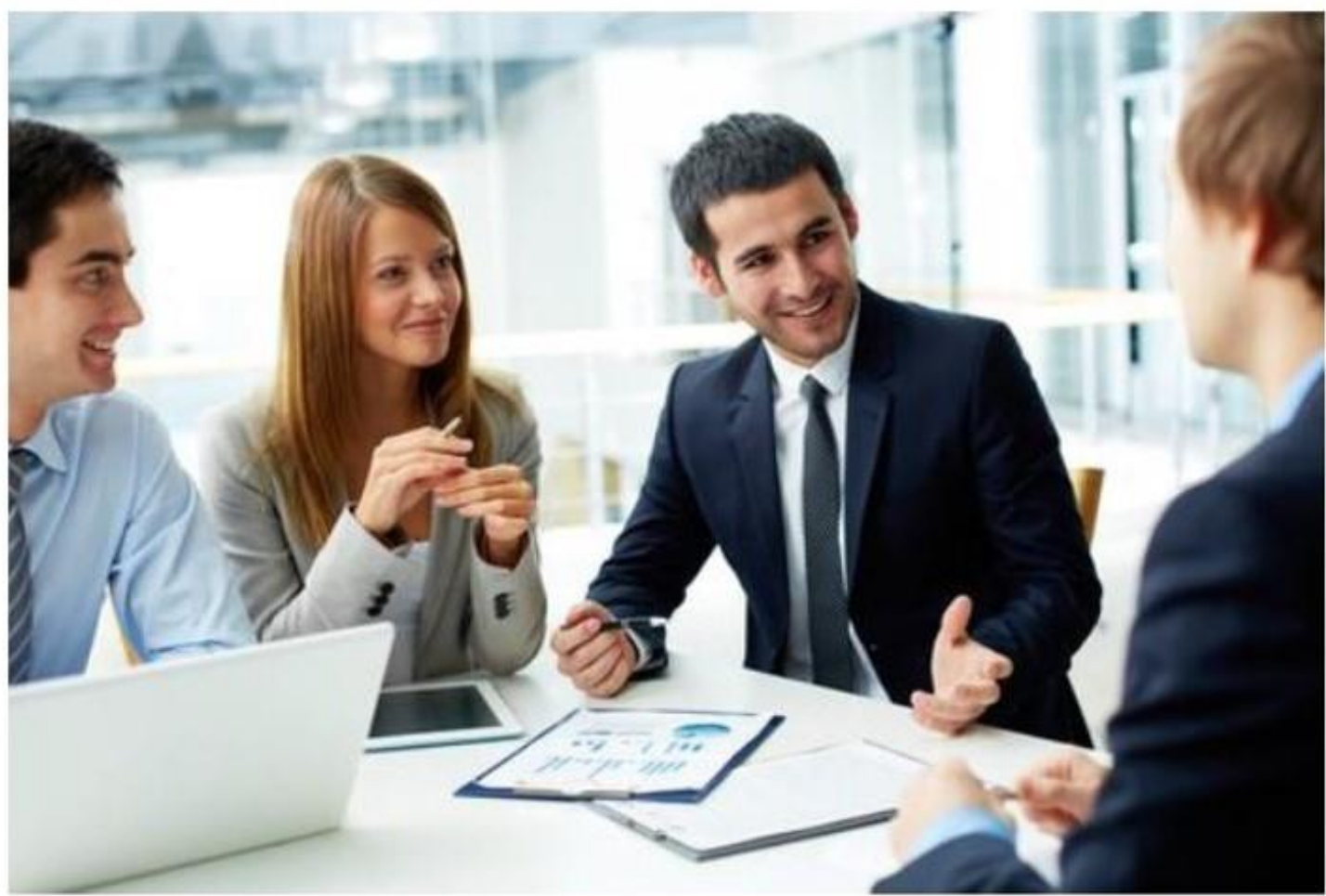

Zdroj: Vlastni (UJP ZČU)

Fig. 5: Zadání k projektu Meine Bank

Komunikačním kanálem pro dva projektové týmy se stal Microsoft Teams, kde výuka probíhala. Byly vytvořeny dva „kanály“, kam měli přístup pouze členové daného kanálu. Zajímavá na Canvě je interaktivní spolupráce při vytváření prezentace nebo sdílení hotových materiálů. Po úpravě je možné materiál uložit a stáhnout v různých formátech (jpg, png, pdf).

Praktické ukázky studentských prezentací zobrazují obrázky Fig. 6 a Fig. 7. 

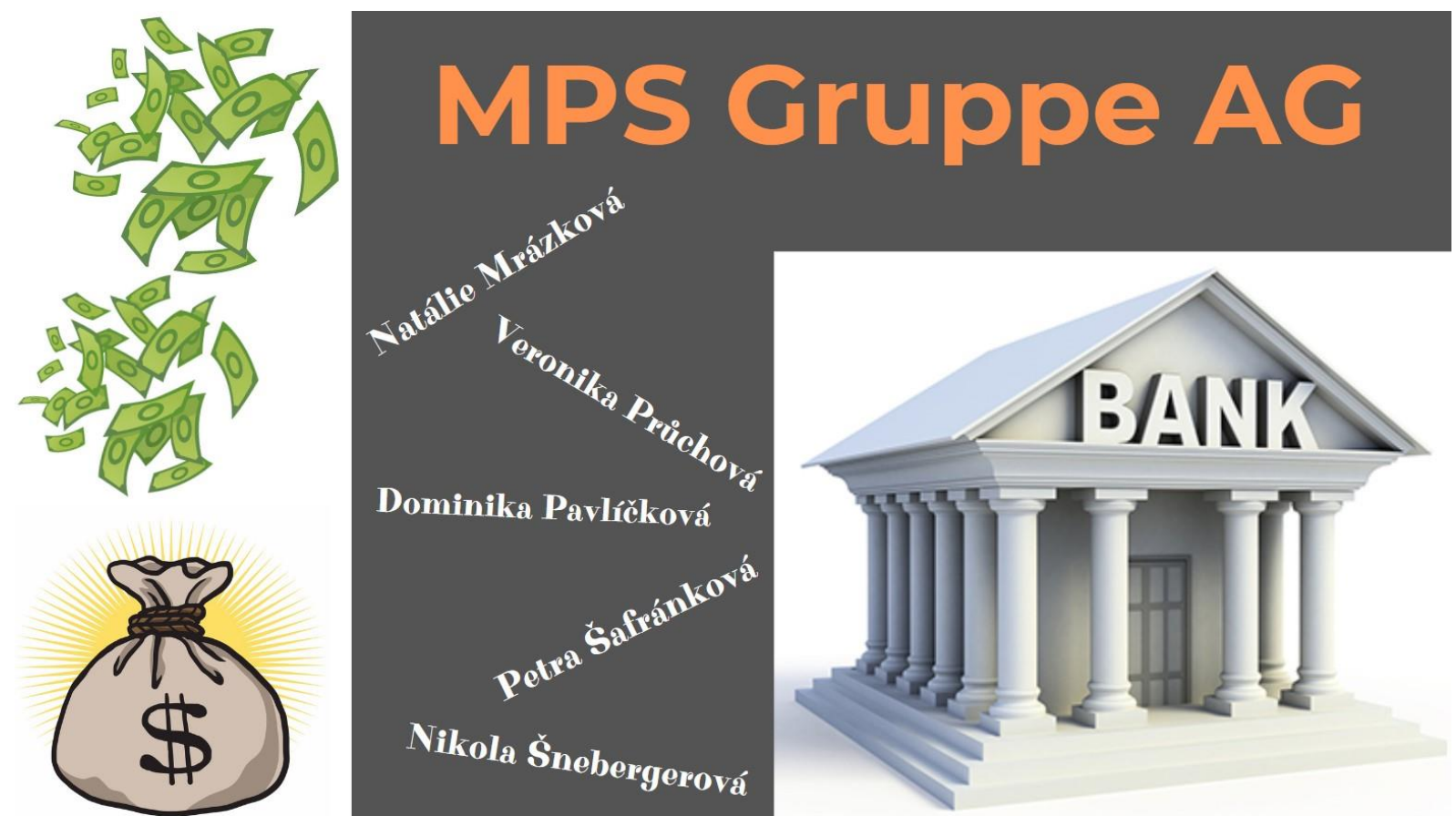

Zdroj: Vlastni (UJP ZČU)

Fig. 6: Meine Bank-príklad MPS Gruppe AG

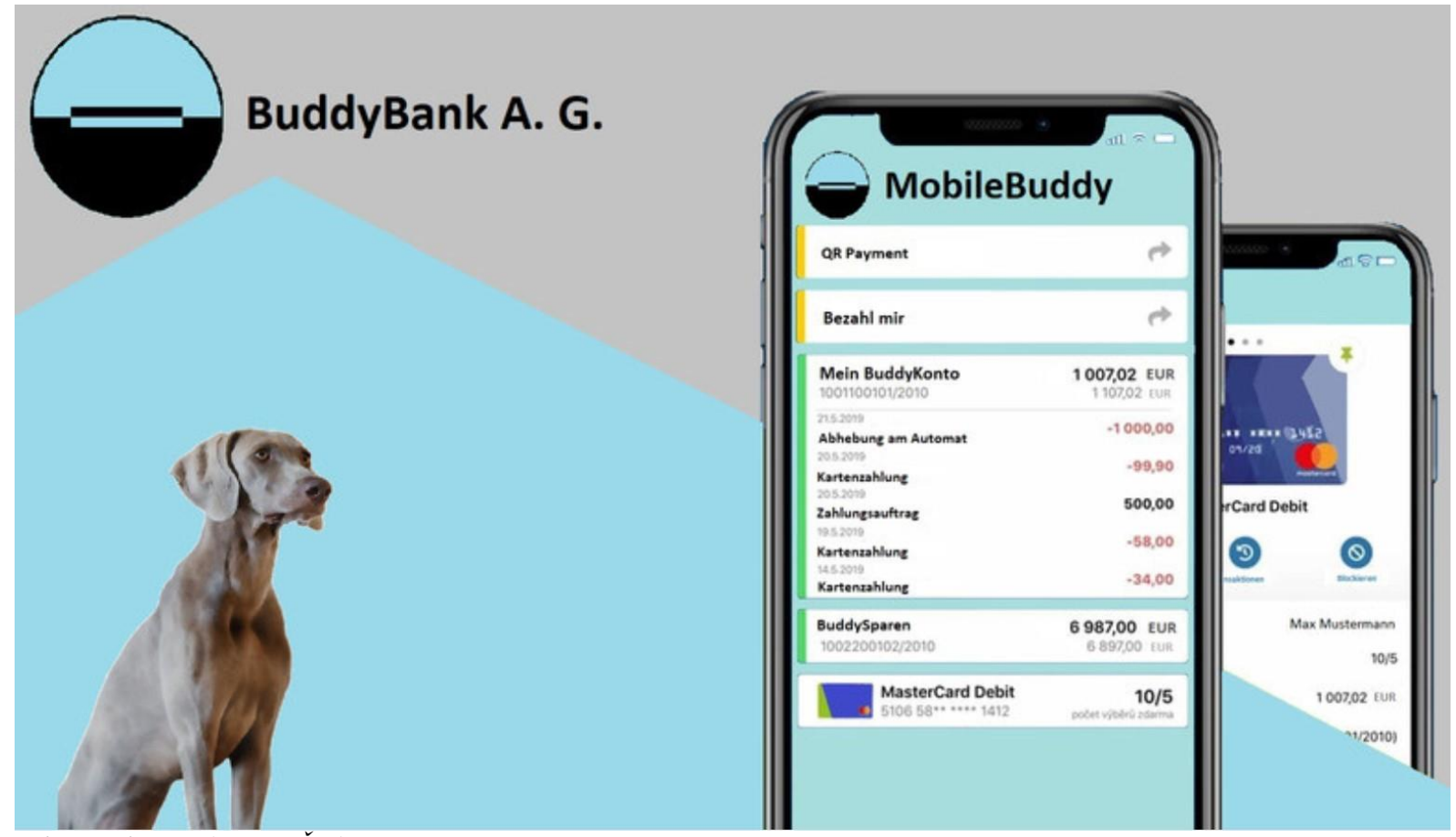

Zdroj: Vlastní (UJP ZČU)

Fig. 7: Meine Bank-príklad BuddyBank, A.G.

Oblíbenost přípravy prezentace v Canvě sleduje rovněž dotazník ve 4. kapitole tohoto článku.

\section{Dotazník oblíbenosti online nástrojů}

Jak byly oba zvolené nástroje u studentů oblíbeny či neoblíbeny, vypovídají jejich odpovědi.

Celkem bylo do předmětu Němčina pro bankovnictví zapsáno 11 studentů a studentek Fakulty ekonomické. Obě aplikace byly všemi hodnoceny velmi pozitivně. Žádné negativní 
hodnocení nedostal ani jeden z nástrojů. Z odpovědí tedy vyplývá, že oba nástroje obdržely, co se oblíbenosti týče, 100 \% kladných hodnocení.

Pro obě aplikace byla použita totožná otázka - Co vám na Edpuzzle/Canvě vyhovovalo/nevyhovovalo?

Př́klady odpovědí:

Canva

- je oproti PowerPointu velmi intuitivní

- prezentace v tomto nástroji mi přijdou po grafické stránce hezči a pokud se člověk nauči s tímto nástrojem pracovat, tak je to vlastně ve finále srovnatelné s PowerPointem. Prezentace v Canvě po grafické stránce vypadají lépe.

- více možnosti, větši přehled, hezčí vzhled prezentací

- zajímavý způsob prezentování

- budu ji využívat i nadále, práce v Canvě je zábavná, prezentace jsou originální

- budu ji využivat i nadále z dưvodu za mě vzhledově zajímavějších prezentací. Vytvárela jsem $v$ ní $i$ videa, loga apod.

- budu ji využivat i dále, protože nabizi více možností než PowerPoint. PowerPoint dnes využivá kde kdo, ale Canvu zatím moc lidí nevyuživá.

- má moc pěkné efekty a hezké šablony

- práce v ní mě moc bavila, odted' už používám jen Canvu, zatím jsem nenašla nic, co by mi nevyhovovalo

EdPuzzle

- je velmi dobrý ve výuce němčiny, poslechy německého jazyka a vytváření otázek jsou super

- zpočátku náročnějši na př́pravu, ale pak to byla zábava

- fajn nástroj, ráda jsem ho poznala

- vyzkoušela jsem si, jak vytvořit zajímavým způsobem úkol pro ostatni studenty

- nástroj pro učení se novým slovíčkưm nebo opakování

- je náročné vytvořit relativně krátký úkol-otázky, odpovědi-celkově hodnotím ale za 1 *

- rozhodně práce v EdPuzzle byla pro mě novinkou a př́nosnou

- vyhovovalo mi, že to bylo něco jiného, nového

\section{Závěr}

Článek se věnuje participaci studentů na tvorbě podpůrných výukových materiálů v nadstavbovém kurzu Němčina pro bankovnictví. Předmět je vyučován v němčině pro studenty Fakulty ekonomické Západočeské univerzity v Plzni. V letním semestru 2020/21 probíhala výuka online na platformě Microsoft Teams. Pro prezentace studentů byly zvoleny interaktivní aplikace EdPuzzle a grafická aplikace Canva. Studenty byly oba vybrané nástroje hodnoceny velmi pozitivně, což nasvědčuje, že byly vybrány správně. 
Přínosem digitálních technologií ve výuce je vyvolat osobní zapojení studentů do výukových aktivit, prostřednictvím internetových aplikací ji oživit a udělat interaktivní.

\section{Literatura}

[1] BABĚRADOVÁ, H.: Fachsprache Deutsch - Finanzen: Kommunikation rund ums Geld. Klett, Praha, 2006. ISBN 80-86906-56-6.

[2] TRUNEČEK, J.: Aplikace pro zvýšení interakce (nejen) při distančním vzdělávání dospělých (2. díl). Andragogika v praxi. [online]. 2021, ročník 8, číslo 26. ISSN 23365145 (Print). ISSN 2694-9490 Available from WWW: https://www.aivd.cz/soubor$\underline{\text { doc5554/ }}$

[3] OKCDV ZČU: Chci tvořit interaktivní prvky. [online]. 2020. [navštíveno 2021-10-26]. Dostupné z WWW: https://czv.zcu.cz/zajisteni-distancni-vyuky/chci-tvorit-interaktivniprvky/

[4] OKCDV ZČU: EdPuzzle. [online]. 2020. [navštíveno 2021-10-26]. Dostupné z WWW: https://czv.zcu.cz/zajisteni-distancni-vyuky/chci-tvorit-interaktivni-prvky/edpuzzle/

[5] GURU VE ŠKOLE: Canva. [online]. 2021. [navštíveno 2021-10-26]. Dostupné z WWW: https://www.guruveskole.cz/canva/ 


\section{StUdents' PARTICIPATION In CREATING SUPPORT MATERIALS IN THE GERMAN FOR BANKING COURSE}

The students of bachelor's degree programmes at the Faculty of Economics of the University of West Bohemia in Pilsen have the opportunity to broaden their knowledge and skills acquired in specialized subjects through additional specialized courses taught in German. The language courses in question aim to prepare students adequately for their professional career as well as to provide them with practical competences. This article focuses on the students' participation in creating the support materials in the German for Banking course. The graphics online tool called Canva was chosen to present the students' projects. The individual students' presentations were created in the form of interactive videos using EdPuzzle, another online tool. The popularity of online tools was also verified using a questionnaire.

\section{Die BETEILIGUNG DER STUDENTEN AN DER ERSTELlUNG UNTERSTÜTZENDER LEHRMATERIALIEN IM FACH DEUTSCH FÜR DAS BANKWESEN}

Die Studenten des Bachelor-Studiums an der ökonomischen Fakultät der Westböhmischen Universität Pilsen haben die Möglichkeit, ihre im Fachstudium erworbenen Fähigkeiten und Kenntnisse mittels auf Deutsch unterrichteter fachlicher Aufbaukurse zu vertiefen. Das Ziel der fachgebundenen Sprachkurse besteht in einer adäquaten Vorbereitung der Studenten auf das Berufsleben und in der Vermittlung auf die Praxis ausgerichteter Kompetenzen. Dieser Beitrag widmet sich der Beteiligung der Studierenden an der Erstellung unterstützender Lehrmaterialien im Fach Deutsch fürs Bankwesen. Für die Vorstellung studentischer Projekte wurde das grafische Online-Instrument Canva gewählt. Die individuellen Präsentationen der Studenten wurden in Form interaktiver Videos mit Hilfe des Online-Instrumentes EdPuzzle erstellt. Die Beliebtheit von Online-Instrumenten wurde in einer Fragebogenaktion überprüft.

\section{UDZIAŁ STUDENTÓW W TWORZENIU WSPOMAGAJĄCYCH MATERIAŁÓW DYDAKTYCZNYCH DLA PRZEDMIOTU JĘZYK NIEMIECKI W BANKOWOŚCI}

Studenci studiów licencjackich Wydziału Ekonomii Uniwersytetu Zachodnioczeskiego w Pilźnie mają możliwość pogłębienia umiejętności i wiedzy zdobytej na zajęciach z przedmiotów specjalistycznych w drodze dodatkowych kursów specjalistycznych nauczanych w języku niemieckim. Celem specjalistycznych kursów językowych jest odpowiednie przygotowanie studentów do życia zawodowego i przekazanie im praktycznych kompetencji. W artykule opisano udział studentów w tworzeniu wspomagających materiałów dydaktycznych dla przedmiotu Język niemiecki w bankowości. W celu przedstawienia projektów studenckich wybrano narzędzie graficzne online Canva. Indywidualne prezentacje studentów wykonano w formie interaktywnych filmików przy pomocy narzędzia online EdPuzzle. Popularność narzędzi online została sprawdzona w drodze ankiety. 